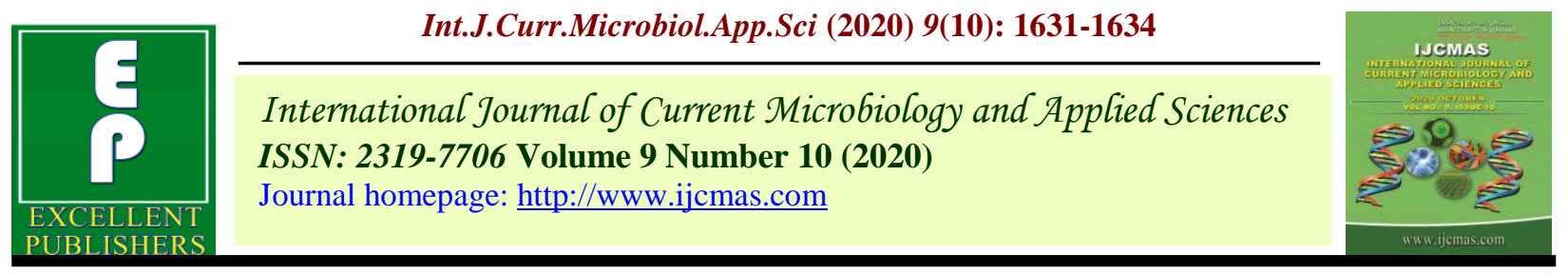

Original Research Article

https://doi.org/10.20546/ijcmas.2020.910.195

\title{
Effect of Foliar Application of Macro and Micronutrients on Fruit Drop, Growth, Yield and Quality of Kinnow Mandarin (Citrus reticulata) on Five-Year-Old Plants
}

\author{
N. Teja Kumar*, V. M. Prasad and Vijay Bahadur \\ Department of Horticulture, Sam Higginbottom University of Agriculture, Technology and \\ Sciences, Prayagraj, Uttar Pradesh, 211007, India \\ *Corresponding author
}

\section{A B S T R A C T}

\begin{tabular}{|l|}
\hline Ke y w or d s \\
Kinnow mandarin \\
(Citrus reticulata), \\
$\begin{array}{l}\text { Macro and } \\
\text { Micronutrients, } \\
\text { Fruitdrop, Growth, } \\
\text { Quality }\end{array}$ \\
\hline Article Info \\
\hline $\begin{array}{l}\text { Accepted: } \\
\text { 12 September 2020 } \\
\text { Available Online: } \\
10 \text { October } 2020\end{array}$ \\
\hline
\end{tabular}

A field experiment was conducted during March to January, 2019-2020 at the Horticulture Research Farm, Department of Horticulture, Naini Agricultural Institute, Sam Higginbottom University of Agriculture, Technology \& Sciences, Prayagraj to study the "Effect of Foliar Application of Macro and Micronutrients on Fruit drop, Growth and quality of Kinnow Mandarin (Citrus reticulata) on Five year old plants under Prayagraj Agro climatic conditions". The experiment was conducted in Randomized Block Design on Kinnow Mandarin (Citrus reticulata) on fruit drop, Growth and quality with 5 various treatments combinations (Control, Urea $-1 \%$, Potassium $-1 \%$, Zinc sulfate $-0.5 \%$, Iron Sulfate $-1 \%$, Boric acid $-0.2 \%$ ) in three replications. The Maximum plant height ranged from $199.46 \mathrm{~cm}$ to $239.64 \mathrm{~cm}$. The minimum plant height $(176.68 \mathrm{~cm})$ was recorded in Control (Water spray) which was significantly over all other treatments. Based on the results obtained, the most number of flowers obtain in Treatment combination of (Urea1\%+Zinc sulfate $0.5 \%+$ Iron sulfate $1 \%$ ), maximum number of fruits per plant (171.45), maximum fruit weight per plant $(110.42 \mathrm{gm})$ and maximum fruit length per plant $(6.30 \mathrm{~cm})$ was found superior at Treatment combination of Urea $1 \%+$ Zinc sulfate $0.5 \%+$ Boric acid $0.2 \%$ ) foliar spray. Among these treatment combinations, the most effective combination of foliar spray for Plant height $(\mathrm{cm})$, number of flowers, fruits per plant, fruit weight, fruit length is (Urea1\%+Zinc sulfate $0.5 \%+$ Boric acid $0.2 \%$ )

\section{Introduction}

Kinnow Mandarin (Citrus reticulata) fruits act as an important constituent of daily nutrition. They are also nutritionally crucial and commercially predominant. Citrus are rich in vitamin-c vitamins (A and B complex) and minerals (calcium, iron, and phosphorus) in diet to keep human health in good state. In
India Citrus is grown in 0.62 million ha. area with the total production of 4.79 million tonnes Kinnow occupies $54.9 \%$ of the area under citrus. It is a hybrid of two citrus cultivars-King (Citrus nobilis) $\mathrm{x}$ willow leaf (Citrus deliciosa). The genus Citus L. belongs to subfamily Aurantioideae of the family Rutaceae. It was first developed by Howard B. Frost in 1915 and released in 1953 at the 
university of California, Citrus experiment station.

\section{Materials and Methods}

The experiment was carried out using Kinnow plants at the Cenral Research field of Department of Horticulture, Naini Agricultural Institute, Sam Higginbottom University of Agriculture, Technology and Sciences, Prayagraj, during the year 20192020. The experiment was conducted in Randomized Block Design with 5 various treatments (Control, Urea -1\%, Pottasium $1 \%$, Zinc sulfate $-0.5 \%$, Iron Sulfate $-1 \%$, Boric acid $-0.2 \%$ ) in three replication. The experimental site is situated at of a latitude of $20^{\circ}$ and $15^{\circ}$ North and longitude of $60^{\circ} 3$ " East and at an altitude of 98 meters above mean sea level (MSL).

\section{Results and Discussion}

Among all the different treatment combination shown in Table -1, the maximum height of the plant was observed in treatment combination foliar spray of Urea $-1 \%$, Zinc sulfate $-0.5 \%$, Boric acid $-0.2 \%$ (239.64 $\mathrm{cm}$ ), the minimum height of the plant was observed in Control (176.68). Maximum number of flowers per plant were observed in Treatment combination foliar spray of Urea $1 \%$, Zinc sulfate $-0.5 \%$, Boric acid $-0.2 \%$ (181.51), and minimum number of flowers were observed in Control (110.30). The maximum number of fruits were observed in treatment combination foliar spray of Urea $1 \%$, Zinc sulfate $-0.5 \%$, Boric acid $-0.2 \%$ (171.45), and the minimum number of fruits were observed in control (95.58) (Fig. 1).

Table.1 Treatment combination data of Foliar application of Macro and micronutrients used for Kinnow mandarin (Citrus reticulata). Here Urea (U), Potassium Sulfate $\left(\mathrm{K}_{2} \mathrm{SO}_{4}\right)$, Zinc sulfate $\left(\mathrm{ZnSO}_{4}\right)$, Iron Sulfate $\left(\mathrm{FeSO}_{4}\right)$, Boric Acid $\left(\mathrm{H}_{3} \mathrm{BO}_{3}\right)$

\begin{tabular}{|c|c|c|c|c|c|c|}
\hline $\begin{array}{l}\text { Treatments } \\
\text { symbols }\end{array}$ & Treatment combination & $\begin{array}{r}\text { Plant height } \\
\text { Maximum }\end{array}$ & $\begin{array}{r}\text { Number of } \\
\text { flowers per } \\
\text { plant }\end{array}$ & $\begin{array}{r}\text { Number of } \\
\text { fruits per } \\
\text { plant }\end{array}$ & $\begin{array}{r}\text { Fruit } \\
\text { weight(g } \\
\mathbf{m})\end{array}$ & $\begin{array}{c}\text { Fruit } \\
\text { length }(\mathrm{cm})\end{array}$ \\
\hline T0 & Control (Water spray) & 216.56 & 110.30 & 95.58 & 96.47 & 4.83 \\
\hline T1 & $\mathrm{U} 1 \%+\mathrm{K} 2 \mathrm{SO} 41 \%$ & 221.80 & 130.26 & 118.47 & 98.43 & 5.54 \\
\hline T2 & $\mathrm{U} 1 \%+\mathrm{ZnSO} 40.5 \% \%$ & 229.80 & 138.57 & 123.68 & 97.38 & 5.41 \\
\hline T3 & $\mathrm{U} 1 \%+\mathrm{FeSO} 41 \%$ & 228.94 & 132.53 & 119.55 & 101.43 & 5.32 \\
\hline T4 & $\mathrm{U} 1 \%+\mathrm{H} 3 \mathrm{BO} 30.2 \%$ & 228.26 & 144.31 & 111.51 & 105.46 & 5.76 \\
\hline T5 & $\mathrm{U} 1 \%+\mathrm{ZnSO} 40.5 \%+\mathrm{FeSO} 41 \%$ & 222.43 & 163.72 & 148.59 & 110.42 & 5.21 \\
\hline T6 & $\begin{array}{l}\mathrm{U} 1 \%+\mathrm{ZnSO} 40.5 \%+\mathrm{H} 3 \mathrm{BO} \\
0.2 \%\end{array}$ & 239.64 & 181.51 & 171.45 & 108.69 & 6.30 \\
\hline T7 & $\mathrm{U} 1 \%+\mathrm{H} 3 \mathrm{BO} 30.2 \%+\mathrm{FeSO} 41 \%$ & 225.14 & 169.51 & 155.37 & 109.57 & 6.26 \\
\hline T8 & $\mathrm{K} 2 \mathrm{SO} 41 \%+\mathrm{ZnSO} 40.5 \%$ & 233.82 & 170.43 & 162.6 & 105.70 & 6.16 \\
\hline T9 & $\mathrm{K} 2 \mathrm{SO} 41 \%+\mathrm{FeSO} 41 \%$ & 232.06 & 180.49 & 169.61 & 107.37 & 5.85 \\
\hline T10 & $\mathrm{K} 2 \mathrm{SO} 41 \%+\mathrm{H} 3 \mathrm{BO} 30.2 \%$ & 228.57 & 162.53 & 149.47 & 106.84 & 5.94 \\
\hline T11 & $\begin{array}{l}\mathrm{K} 2 \mathrm{SO} 41 \%+\mathrm{ZnSO} 40.5 \%+\mathrm{FeSO} 4 \\
1 \%\end{array}$ & 233.85 & 155.74 & 138.56 & 99.49 & 5.64 \\
\hline T12 & $\begin{array}{l}\mathrm{K} 2 \mathrm{SO} 41 \%+\mathrm{ZnSO} 40.5 \%+ \\
\mathrm{H} 3 \mathrm{BO} 30.2 \%\end{array}$ & 230.73 & 166.72 & 140.35 & 101.33 & 6.21 \\
\hline \multirow[t]{4}{*}{ T13 } & $\begin{array}{l}\mathrm{K} 2 \mathrm{SO} 41 \%+\mathrm{H} 3 \mathrm{BO} 30.2 \%+\%+ \\
\text { FeSO4 } 1 \%\end{array}$ & 227.88 & 167.38 & 142.54 & 106.48 & 6.24 \\
\hline & F-test & $\mathbf{S}$ & $\mathbf{S}$ & $\mathbf{S}$ & $\mathbf{S}$ & $\mathbf{S}$ \\
\hline & C. D. at $0.5 \%$ & 1.426 & 0.223 & 0.279 & 23.315 & 0.295 \\
\hline & S.Ed. $( \pm)$ & 1.928 & 0.302 & 0.377 & 31.518 & 0.399 \\
\hline
\end{tabular}




\section{Fig.1 Field visit}

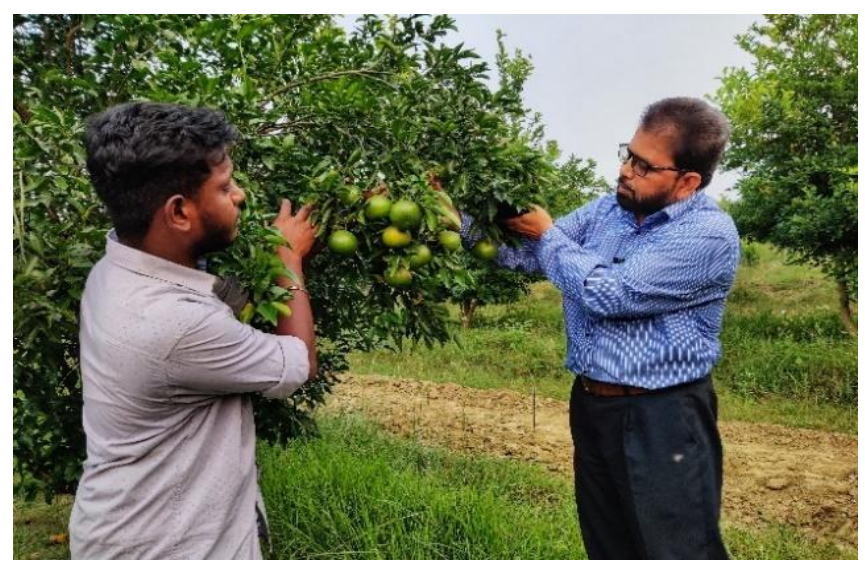

The maximum fruit weight was observed in treatment combination foliar spray of Urea $1 \%$, Zinc sulfate $-0.5 \%$, Iron sulfate $1 \%$ (110.42gm) and a minimum fruit weight was observed in control $(96.47 \mathrm{gm})$. The maximum fruit length was observed in treatment combination foliar spray of Urea $-1 \%$, Zinc sulfate $-0.5 \%$, Boric acid $-0.2 \%(6.30 \mathrm{~cm})$, minimum fruit length observed in control $(4.83 \mathrm{~cm})$. The maximum fruit yield per plant was observed in treatment combination foliar spray of Urea $-1 \%$, Zinc sulfate $-0.5 \%$,Iron sulfate $1 \%(18.32 \mathrm{~kg})$. Among all the treatments combinations, maximum total soluble solids (50.74) was observed in foliar spray of Urea $-1 \%$, Zinc sulfate $-0.5 \%$, Boric acid $-0.2 \%$. The maximum Vitamin-c (24.42) was observed in foliar spray of Urea $-1 \%$, Zinc sulfate $-0.5 \%$, Boric acid $-0.2 \%$.

Based on the result obtained, the most effective Treatment combination of foliar spray for optimum Plant height, number of flowers, fruit per plant, fruit weight, fruit length, Yield is found to be T6, having the proportions (Urea $-1 \%$, Zinc sulfate $-0.5 \%$, Boric acid -0.2\%.) as shown in Table 1.

\section{References}

Alloway, B. J., Zinc in Soils and Crop Nutrition. International Zinc
Association Brussels, Belgium (2008).

Gurjar, M. K., R. A. Kaushik, and P. Baraily. "Effect of zinc and boron on the growth and yield of Kinnow mandarin." International Journal of Scientific Research 4 (2015): 207-208.

Chandler, W. H., Acid citrus fruits, Evergreen orchards. Lea and Febiger, Philadelphia (1958).

Ibrahim, M., et al., "Effect of micronutrients on citrus fruit yield growing on calcareous soils." Advances in plant and animal boron nutrition (2007): 179-182.Gopalkrishana, N. and Ekbote, A. A. P., Pre-harvest Fruit Drop- Its possible causes and control with growth regulators: A Review. Punjab Journal of Horticulture, 2: 167 (1962).

Gurjar, P. S. and Rana, G. S., Influence of foliar application of nutrients and growth regulator on fruit drop, yield and fruit size and quality in Kinnow mandarin. Indian Journal of Horticulture, 71(1): 109-111 (2014).

Kaur, Nirmaljit, et al., "Effect of micronutrients on leaf composition, fruit quality and yield of Kinnow mandarin." Journal of Applied and Natural Science 7.2 (2015): 639-643.

Ullah, S., et al., 2012. Foliar application of boron influences the leaf mineral 
status, vegetative and reproductive growth, yield and fruit quality of 'Kinnow' mandarin (Citrus reticulata
Blanco.). Journal of Plant Nutrition, 35.13: 2067-2079.

\section{How to cite this article:}

Teja Kumar, N., V. M. Prasad and Vijay Bahadur. 2020. Effect of Foliar Application of Macro and Micronutrients on Fruit Drop, Growth, Yield and Quality of Kinnow Mandarin (Citrus reticulata) on Five-Year-Old Plants. Int.J.Curr.Microbiol.App.Sci. 9(10): 1631-1634. doi: https://doi.org/10.20546/ijcmas.2020.910.195 